\author{
Ewa Jarosz \\ Uniwersytet Śląski w Katowicach \\ ewa-jarosz@post.pl \\ Cezary Kurkowski \\ Uniwersytet Warmińsko-Mazurski w Olsztynie \\ cezary.kurkowski@uwm.edu.pl
}

\title{
Przemoc w wychowaniu w świetle opinii społecznej oraz relacji rodziców - zarys problemu na tle raportu Rzecznika Praw Dziecka
}

\begin{abstract}
Rzeczpospolita Polska zapewnia ochronę praw dziecka. Każdy ma prawo żądać od organów władzy publicznej ochrony dziecka przed przemoca, okrucieństwem, wyzyskiem i demoralizacją.
\end{abstract}

Art. 72 Konstytucja Rzeczpospolitej

\begin{abstract}
Summary
Violence in upbringing in light of public opinion and parents' accounts an outline of the problem based on the report of the Ombudsman for Children

The paper describes the results of the survey focused on the social attitudes towards violence in upbringing made in 2015. The survey is a means of monitoring violence against children carrying out by the Ombudsman for Children since 2011. The research findings reveal a declining tendency in violence in upbringing acceptance over the study period. However, the violence in upbringing acceptance among the Poles remains at a high level. The survey shows that too many Poles consider beating children to be an effective method of upbringing and that too many parents use spanking and beating in their everyday relations with children. The final part of the paper concentrates on the possible solutions to stop using corporal punishment in Poland.
\end{abstract}

Słowa kluczowe: przemoc w wychowaniu, przemoc wobec dzieci, przemoc domowa, Rzecznik Praw Dziecka

Keywords: violence in upbringing, violence against children, domestic violence, Ombudsman for Children 
W listopadzie 2015 roku po raz piąty ukazał się raport na temat postaw społecznych wobec przemocy w wychowaniu, pt. „Przemoc w wychowaniu w opinii społecznej oraz w relacjach rodziców". Badania zrealizowano w ramach monitoringu problemu przemocy wobec dzieci prowadzonego przez Rzecznika Praw Dziecka. Pierwsze badania w tym względzie zrealizowano w 2011 roku jako jeden z elementów wypełnienia ustawowego zobowiązania dotyczącego przedstawienia przez rzecznika sprawozdania na temat skutków obowiązywania ustawy nowelizującej prawo o przeciwdziałaniu przemocy w rodzinie z 2010 roku. Od tamtego czasu badanie opinii publicznej na temat akceptacji przemocy w wychowaniu realizowane jest corocznie na reprezentatywnej próbie dorosłych Polaków. Od roku 2014 do badań wprowadzono kwestie stosowania przemocy w wychowaniu przez rodziców ukazywane w perspektywie ujawnień (relacji) rodziców (Jarosz 2015).

Badania surveyowe do raportu w roku 2015 zrealizowała agencja TNS Polska na reprezentatywnej próbie 1017 dorosłych Polaków (w tym 283 rodziców dzieci do 18 roku życia) w dniach 4-9 września metodą CAPI (poprzez bezpośrednie wywiady ankieterskie wspierane komputerowo). Uzyskane dane poddano analizie ilościowej, a następnie opisowi statystycznemu, jak również odniesiono je do wyników poprzednich edycji badań - z lat 2011-2014 (Jarosz 2015), oraz do wyników podobnych badań przeprowadzonych przed wprowadzeniem zakazu bicia dzieci w 2010 roku, tworząc zestawienia porównawcze ukazujące dynamikę wybranych wskaźników².

Raport z roku 2015 ukazuje problem postaw społecznych wobec przemocy w wychowaniu w kilku aspektach ${ }^{3}$ :

- aprobaty dla zachowań przemocy wobec dzieci (bicia i uderzania),

- uznawania bicia za metodę wychowawczą,

- akceptacji kar cielesnych w wychowaniu,

- podejmowania interwencji w rodzinę z problemem przemocy w wychowaniu oraz preferencji co do ich charakteru,

- osobistego reagowania na sytuacje występowania przemocy wobec dziecka,

- osobistego stosowania przemocy w wychowaniu przez rodziców (w perspektywie zachowań przemocy fizycznej i psychicznej).

W raporcie podjęto również próbę uchwycenia różnic w społecznej aprobacie zachowań przemocy oraz w stosowaniu zachowań przemocy ze względu na płeć dziecka.

Poniżej zaprezentowano wybrane aspekty z raportu ze szczególnym zwróceniem uwagi na społeczną aprobatę zachowań przemocowych wobec dzieci („klapsów” i „lania”), akceptacji bicia dzieci jako metody wychowawczej oraz pokazano relacje rodziców na temat ich ujawnienia zachowań przemocowych wobec dzieci.

\footnotetext{
Dane raportu prezentowane są w skrócie na stronie http://brpd.gov.pl/aktualnosci/bicie-czas-z-tymskonczyc-rusza-kampania-spoleczna-rzecznika-praw-dziecka.

2 Autorką raportów od 2011 roku jest Ewa Jarosz. W roku 2015 w opracowaniu danych udział wziął Cezary Kurkowski.

3 Pełna wersja raportu ukaże się w corocznym sprawozdaniu Rzecznika Praw Dziecka pt. Informacja o działalności Rzecznika Praw Dziecka za rok 2015 (http://brpd.gov.pl/sprawozdania-z-dzialalnosci).
} 


\section{Społeczna aprobata przemocy $w$ wychowaniu}

W celu analizy postaw społecznych dotyczących poziomu akceptacji bicia dzieci w kontekście ich wychowania starano się ustalić poziom aprobaty społecznej dla zachowania, jakim jest uderzanie dziecka (tzw. klapsów) oraz bicie dziecka (tzw. lania). Uzyskane dane pokazują, iż ponad połowa badanych akceptuje uderzanie dziecka (tzw. klapsy). Dane porównawcze $\mathrm{z}$ lat 2011-2015, uzupełnione o dane $\mathrm{z}$ badań zrealizowanych przed wprowadzeniem w Polsce prawnego zakazu kar cielesnych (badania CBOS 2008) wskazują jednak na pozytywną tendencję spadku społecznej aprobaty klapsów (zob. wykres 1).

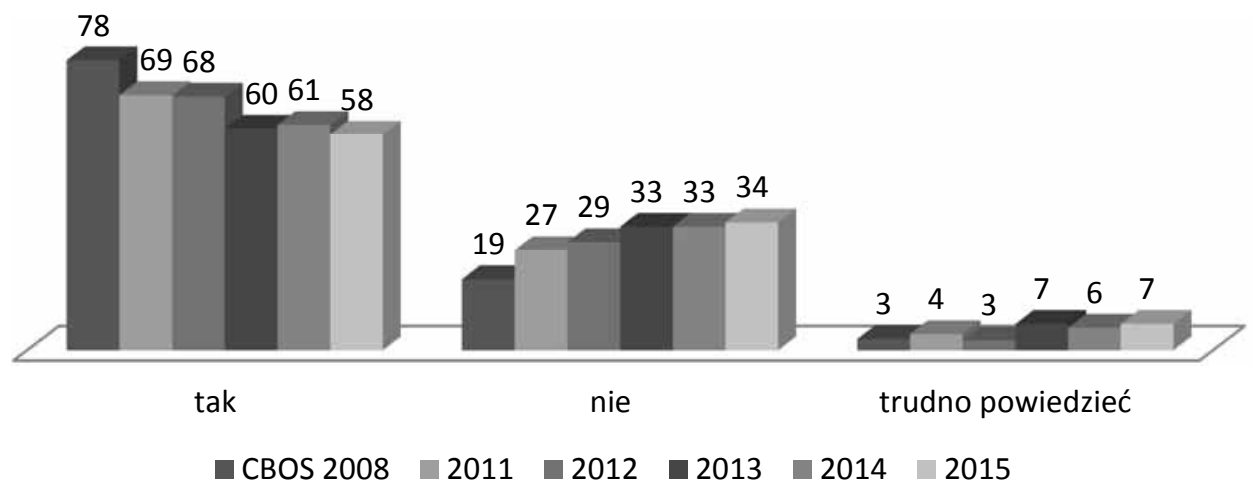

Wykres 1. Społeczna aprobata klapsów w latach 2008-2015 (dane w \%)

Źródło: „Przemoc w wychowaniu w opinii społecznej oraz w relacjach rodziców”. Raport Rzecznika Praw Dziecka, http://www.niedlabicia.pl/download/raport.pdf, s. 1 .

Analizując powyższy wykres można zauważyć $20 \%$ spadek liczby respondentów aprobujących klapsy oraz wzrost o 15\% przeciwników tych zachować w stosunku do roku 2008. Warto również podkreślić, iż wśród rodziców dzieci do 18 roku życia, poziom aprobaty klapsów jest nieco niższy, a jednocześnie wyższy jest poziom dezaprobaty. Różnice można interpretować jako efekt dokonującej się pokoleniowej zmiany w zakresie aprobaty przemocowego traktowania dziecka $\mathrm{w}$ wychowaniu zwłaszcza $\mathrm{w}$ obliczu towarzyszącej tym danym zauważonej prawidłowości, iż osoby starsze częściej aprobują klapsy. Rozkłady danych na temat aprobaty „klapsów” w perspektywie cech demograficznych i społecznych sugerują, poza wspomnianym wpływem wieku osób badanych, istnienie następujących korelacji:

- im wyższe wykształcenie tym częściej osoby nie aprobują klapsów,

- im gorsza ocena własnej sytuacji materialnej tym częstsza aprobata klapsów,

- posiadanie dzieci oraz ich większa liczba w rodzinie zwiększają częstość aprobaty klapsów, 
- w wyraźny sposób na poziom aprobaty klapsów wpływa doświadczania podobnych zachowań w dzieciństwie, tzn. im częściej badani osobiście doświadczali klapsów tym częściej je aprobują,

- wiedza o tym, iż bicie dziecka jest niezgodne z prawem nie zmniejsza aprobaty klapsów, co oznacza przede wszystkim, iż klapsy nie są spostrzegane jako bicie dziecka, które jest zakazane prawem.

Jak wynika z raportu, społeczna aprobata tzw. „lania” dzieci, w roku 2015 nadal jest wysoka i utrzymuje się na podobnym poziomie w perspektywie ostatnich lat (zob. wykres 2), choć jej dynamika jest raczej spadkowa, a wyraźna w porównaniu w dłuższym okresie.

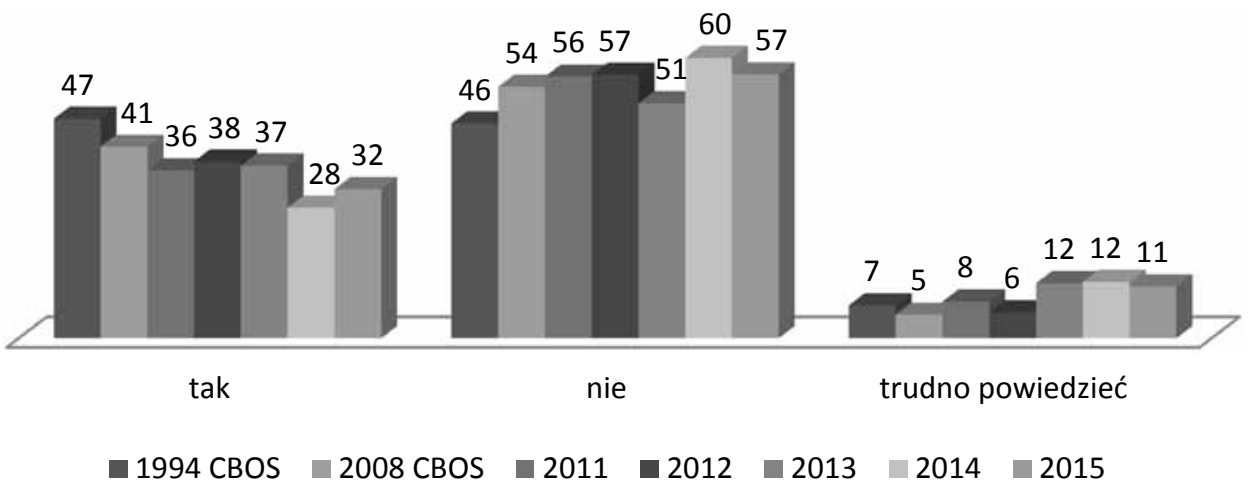

Wykres 2. Społeczna aprobata tzw. lania w latach 1994-2015 (dane w \%)

Źródło: „Przemoc w wychowaniu w opinii społecznej oraz w relacjach rodziców”. Raport Rzecznika Praw Dziecka, http://www.niedlabicia.pl/download/raport.pdf, s. 2.

Warto również zwrócić uwagę na cechy społeczne, demograficzne i indywidualne wpływające na poziom aprobaty bicia dzieci, w świetle których to zestawień danych widać, iż:

- kobiety częściej są przeciwne biciu dzieci,

- częściej przeciwne biciu dzieci są osoby lepiej wykształcone,

- częściej aprobują bicie dzieci oceniający swoją sytuację materialną jako złą,

- osoby starsze częściej aprobują bicie dzieci niż osoby młodsze,

- „aktualni” rodzice nieco rzadziej niż ogół społeczeństwa oraz osoby posiadające dzieci w tym dorosłe, wyrażają aprobatę dla bicia, a częściej są jego przeciwnikami,

- doświadczenia osobiste przemocy w dzieciństwie wpływają wyraźnie na aprobatę bicia dzieci, tzn. im częściej badani doświadczali tzw. lania tym częściej to zachowanie wobec dziecka aprobują.

W raporcie istotną analizowaną kwestią jest traktowanie bicia jako metody wychowawczej. Dane w tym względzie, prezentowane w ujęciu dynamicznym w kolejnych latach ukazuje wykres 3 . 


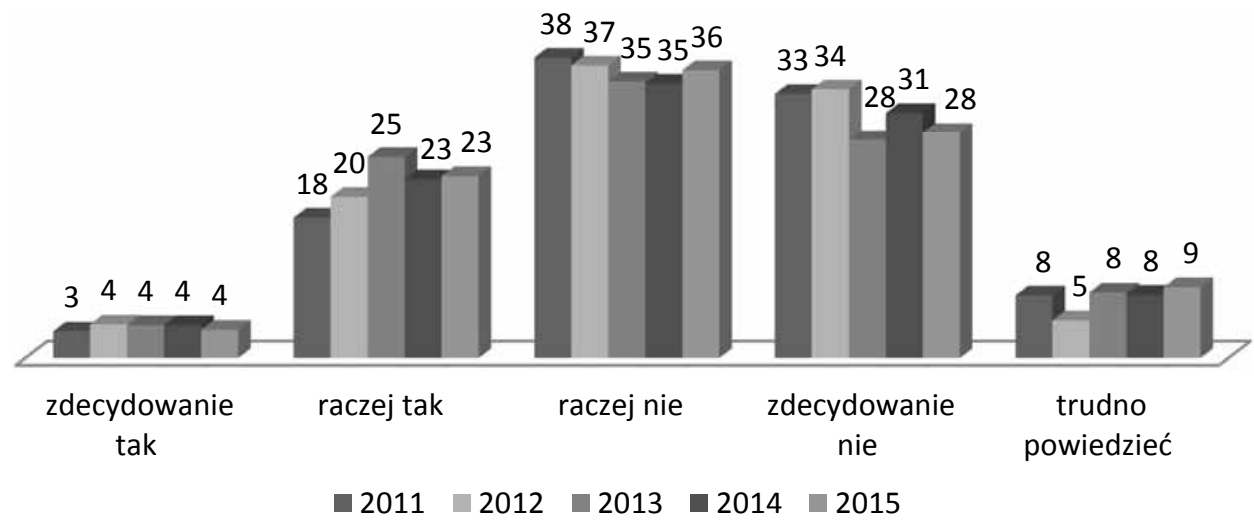

Wykres 3. Uznawanie bicia za metodę wychowawczą w latach 2011-2015 (dane w \%)

Źródło: Opracowanie własne autorów artykułu na podstawie raportu „Przemoc w wychowaniu w opinii społecznej oraz w relacjach rodziców".

Z przedstawionego obrazu danych wynika, iż częściej niż co czwarty Polak (27\%) uznaje bicie za metodę wychowawczą, co wskazuje na mało korzystny obraz kultury pedagogicznej Polaków. Co więcej, porównując wyniki z ostatnich lat dostrzec można, brak pożądanych zmian w postawach społecznych pod tym względem - dane w zakresie aprobaty nie maleją ale co gorsza wskaźniki dezaprobaty uznawania bicia za metodę wychowawczą spadają. To oznacza i liczba osób widzących w biciu skuteczną metodę wychowawczą nieznacznie co prawda ale wzrasta. Uznawanie bicia za skuteczną metodę wychowawczą jest związane z cechami społecznymi i indywidualnymi. Okazuje się, iż częściej stanowisko to prezentują osoby starsze. Z kolei im wyższe wykształcenie, tym częściej badani oponowali przeciwko uznaniu bicia za metodę wychowawczą. Częściej bicie jako metodę wychowawczą spostrzegali badani oceniający swoją sytuację materialną jako złą. Okazało się nadto, iż uznawanie bicia dzieci za metodę wychowawczą zależy od własnych doświadczeń przemocy w dzieciństwie, tzn. im częściej badani doznawali takich zachowań jak klapsy czy lanie, tym częściej widzą w biciu metodę wychowawczą. W wynikach uwidoczniła się też prawidłowość, iż badani rodzice tym częściej uznają bicie za skuteczną metodę wychowawczą, im częściej osobiście stosują przemoc w postępowaniu z dzieckiem.

\section{Stosowanie przemocy w wychowaniu w świetle relacji rodziców}

W treści prezentowanego raportu analizowanym zagadnieniem jest także zakres występowania zachowań przemocowych stosowanych przez rodziców wobec dzieci. W świetle bezpośrednich ujawnień rodziców $(\mathrm{N}=283)$ można stwierdzić, iż zakres występowania przemocy w wychowaniu w postaci tzw. klapsów jest w Polsce nadal poważny, tzn. większość rodziców (54\%) przyznaje się do zastosowania tej formy przemocy wobec własnych dzieci, w tym $21 \%$ z nich do wykorzystywania klapsów częściej niż „,raz lub kilka razy” (wykres 4) 


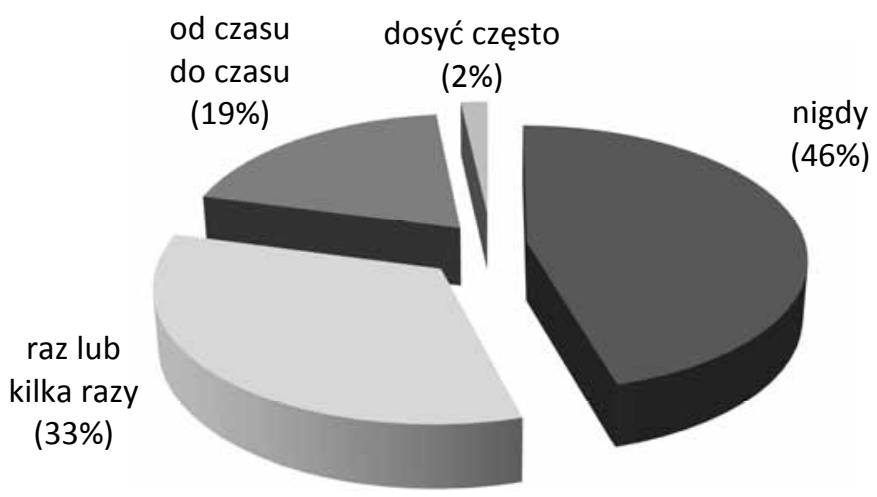

Wykres 4. Czy zdarzyło się Panu/Pani wymierzyć swojemu dziecku klapsa? (N = 283)

Źródło: Opracowanie własne autorów artykułu na podstawie raportu „Przemoc w wychowaniu w opinii społecznej oraz w relacjach rodziców".

W badaniach okazało się także, iż jakkolwiek zdecydowana większość rodziców twierdzi, iż ich dziecko nigdy nie doświadczyło lania, to jednak niemal co dziesiąty rodzic (9\%) przyznał się do występowania takich sytuacji co najmniej raz lub kilka razy (wykres 5).

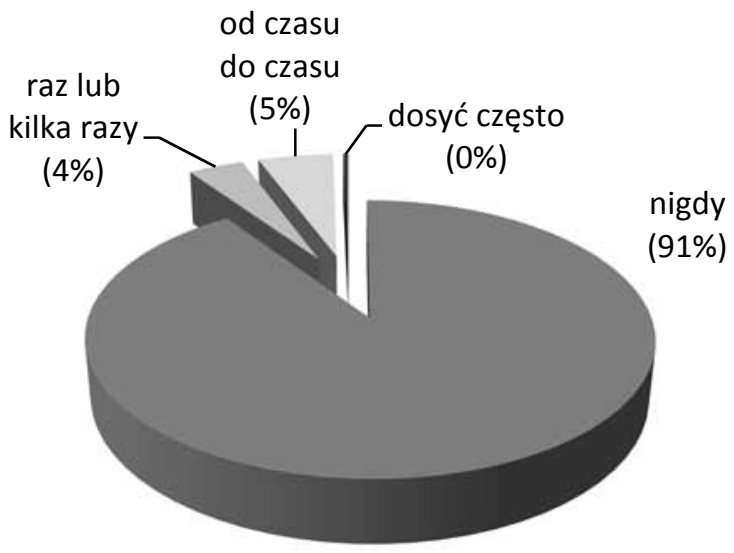

Wykres 5. Czy zdarzyło się, że Pana/Pani dziecko dostało tzw. lanie? $(\mathrm{N}=283)$

Źródło: Opracowanie własne autorów artykułu na podstawie raportu „Przemoc w wychowaniu w opinii społecznej oraz w relacjach rodziców".

Te rezultaty, w świetle samego sposobu badania (bezpośrednie wywiady, czyli wywiady „twarzą w twarz”) należy interpretować jako obrazujące niebagatelne rozmiary w naszym społeczeństwie problemu bicia dzieci, przyjmując iż znacząca część rodziców w takim kontekście ma trudność z przyznaniem się do zachowań przemocowych wobec dziecka. 
Raport ilustruje również inne zachowania przemocowe rodziców wobec dzieci takie, jak: karmienie na siłę, szarpanie, popychanie lub potrząsanie, spoliczkowanie, ciągnięcie za włosy lub uszy, szczypanie, ściskanie ze złością, krzyczenie, obraźliwe, poniżające epitety. W wyniku analizy odpowiedzi rodziców co do poszczególnych zachowań ustalono, iż od kilku do kilkunastu procent rodziców ma skłonność do wykorzystywania przemocy w wychowaniu (w zależności od zachowania), tj. ${ }^{4}$ :

- 7\% rodziców przyznało się do bicia dziecka z użyciem przedmiotu,

- co siódmy rodzic przyznał się do siłowego karmienia swojego dziecka (13\% badanych),

- szarpanie, popychanie, potrzasanie dzieckiem ujawniło łącznie $14 \%$ badanych rodziców,

- spoliczkowaniu dziecka zaprzeczyli niemal wszyscy badani rodzice, jedynie $3 \%$ przyznało się do takiego potraktowania dziecka,

- do ciagnięcia za włosy, uszy przyznało się 8\% rodziców,

- do zachowania polegającego na złośliwym szczypaniu lub ściskaniu części ciała dziecka przyznał się co dziesiąty rodzic (11\%),

- zdecydowana większość badanych rodziców (67\%) przyznała się do krzyczenia na dziecko,

- do obraźliwego nazywania dziecka, zwracania się do dziecka przyznał się częściej niż co dziesiąty rodzic $(12 \%)$.

Jeśli porównać relacje rodziców dotyczące poszczególnych rodzajów zachowań przemocowych rodziców w stosunku do dziecka można zauważyć, iż rodzice najczęściej przyznają się do krzyczenia na dziecko oraz do stosowania wobec dziecka klapsów, najrzadziej natomiast przyznają się do poniżającego w wymiarze kulturowego znaczenia Uzyskany obraz skłania także do wniosku, iż wysoki odsetek ujawnień klapsów i krzyczenia na dziecko jest wynikiem nietraktowania tych zachowań przez rodziców, jako przemocy wobec dziecka.

\section{W kierunku ograniczania w wychowaniu - rekomendacje raportu}

Na zakończenie warto również wskazać rekomendacje wynikające z uzyskanych rezultatów badań. W raporcie zostały one sformułowane w kilku obszarach ${ }^{5}$ :

\section{Edukacja}

Po pierwsze potrzebne jest rozwijanie różnych form i treści edukacji społecznej, zarówno ogólnej, jak i ukierunkowanej, czyli adresowanej do określonych grup: - rodziców, wychowawców, nauczycieli oraz dzieci. Treści edukacji z strony powinny dotyczyć istoty i rodzajów zachowań przemocowych wobec dzieci. społeczeństwo powinno się wyjaśniać

4 Informacja Rzecznika Praw Dziecka o działalności za rok 2015 (http://brpd.gov.pl/sprawozdania-z-dzialalnosci).

5 Tamże. 
szkodliwy, krzywdzący dla dziecka charakter zachowań przemocy w tym tzw. niewinnych klapsów. Ważne jest także aby zachowania te były nominowane jako łamiące prawa dziecka. Z drugiej strony edukacja społeczna powinna pokazywać konstruktywne, bezprzemocowe sposoby radzenia sobie $\mathrm{z}$ dzieckiem. Ważne aby działania te miały charakter systematyczny oraz aby programy edukacyjne prowadzone były w ramach istniejących możliwości dostępu do poszczególnych grup: rodziców, nauczycieli, dzieci. Istotną rolę pełnią w tym względzie cykliczne kampanie społeczne, których efektywność została już wykazana. Warto jednak aby były działania takie, w tym kampanie poddawane były ewaluacjom w celu identyfikowania efektywnych elementów oddziaływania.

\section{2. Świadomość prawna}

Rezultaty raportu 2015 uwidaczniają potrzebę stałego upowszechniania wiedzy o istnieniu w polskim prawie przepisu zakazującego wykorzystywania kar cielesnych w wychowaniu oraz potrzebę szerszego informowania o jego funkcji oraz motywach jego wprowadzenia. Wydaje się, iż szczególnie intensywnie informacja ta powinna być kierowana do rodziców, a także do osób pracujących z dziećmi i rodzicami. Z pewnością trudno jest w polskim społeczeństwie w sposób zdecydowany promować nadrzędność potrzeby ochrony dziecka i jego praw nad tradycyjnymi normami podnoszącymi wartość autonomii i prywatność rodziców w sprawach postępowania z dzieckiem. Należy wyraźnie akcentować w różnych formach społecznych przekazów, iż swoboda rodziców w wychowaniu i poszanowanie ich autonomii i prywatności jest ograniczona dobrem dziecka, oraz iż samo dziecko nie może być traktowane jako własność a wychowanie nie może być polem samowoli rodziców. Jednocześnie wydaje się, iż w społecznym eksponowaniu tej kwestii nie należy przeciwstawiać sobie praw rodziców i praw dziecka.

\section{Kultura pedagogiczna rodziców}

W świetle przedstawionego obrazu rozmiarów zjawiska bez wątpienia podstawowym wskazaniem są działania podnoszące kulturę pedagogiczną rodziców, zwłaszcza w postaci promowania pozytywnego rodzicielstwa oraz kształcenia umiejętności radzenia sobie z dzieckiem, dyscyplinowania go w sposób bezprzemocowy. Ale także potrzebne są intensywne działania w kierunku wyjaśniania rodzicom charakteru i szkodliwości różnych zachowań prezentowanych wobec dzieci, które w swym znaczeniu są przemocą i szkodzą dzieciom.

Przedstawione w skrócie wyniki raportu jedynie zarysowują niektóre aspekty problemu przemocy w wychowaniu, który wydaje się być w ich świetle dość znaczącym problemem społeczno-wychowawczym w Polsce. Niektóre dane raportu Rzecznika Praw Dziecka zostały opublikowane w 2015 r. na stronie internetowej kampanii przeciwko biciu dzieci www.niedlabicia.pl. Pełna wersja raportu zostanie przedstawiona w specjalnej publikacji, która ukaże się w 2016 roku. Szersze przedstawienie problemu przemocy w wychowaniu na tle monitoringu Rzecznika Praw Dziecka zaprezentowane zostanie w jednym z kolejnych numerów „Problemów Wczesnej Edukacji”. 


\section{Literatura}

Jarosz E. (2015), Przemoc w wychowaniu; Między prawnym zakazem a społeczna akceptacją. Monitoring Rzecznika Praw Dziecka, Biuro Rzecznika Praw Dziecka, Warszawa. W pełnej wersji dostęp na: http://brpd.gov.pl/ksiazki-informatory-poradniki/przemoc-w-wychowaniu-miedzyprawnym-zakazem-spoleczna-akceptacja

\section{Źródla internetowe}

Rzecznik Praw Dziecka: http://brpd.gov.pl/aktualnosci/bicie-czas-z-tym-skonczyc-rusza-kampaniaspoleczna-rzecznika-praw-dziecka (20.12.2015)

Kampania społeczna Rzecznika Praw Dziecka: http://www.niedlabicia.pl 